\title{
Will tree colonisation increase the risks of serious performance loss of engineered covers under climate change in Québec, Canada?
}

\author{
Y-D Botula Université du Québec en Abitibi-Témiscamingue, Canada \\ M Guittonny Université du Québec en Abitibi-Témiscamingue, Canada \\ B Bussière Université du Québec en Abitibi-Témiscamingue, Canada \\ É Bresson Polytechnique Montréal, Canada
}

\begin{abstract}
In Québec (Eastern region of Canada), some mine sites have been reclaimed with engineered covers to control acid mine drainage generation. Under humid climate, used covers are mainly oxygen barrier covers. Their performance is based on the maintenance of a high level of water saturation in cover layers that decreases oxygen ingress down to reactive mine wastes. After mine closure, natural colonisation of plant species adapted to current climate conditions takes place gradually on the covers. Plants, especially trees with deep rooting, can affect the water balance of the cover materials. If water saturation decreases in cover materials due to root colonisation, it can cause oxygen ingress to the mine wastes. Numerical models used to predict cover water balance integrate vegetation effects mainly through the use of leaf area index (LAI), root maximal depth ( $\left.R t_{\text {max }}\right)$, and root length density (RLD) as input parameters. By 2100, a northward shift of the distribution of some tree species is predicted from temperate to boreal regions of Canada because of climate change (CC).

In this paper, the Lorraine abandoned mine site reclaimed with a cover with capillary barrier effect (CCBE) and surrounded by a boreal mixed wood forest was used as a case study. CC projections, woody species inventories, and bibliographical research of tree species distribution changes and associated values of key parameters were conducted. All the information collected, along with CC projection data, has helped anticipate potential effects on cover water balance components in the context of CC for the Québec region. At the Lorraine mine site, future dominance of shallow-and medium-rooted deciduous tree species and decline of shallow-and deep-rooted coniferous tree species with CC will have impacts on the CCBE water balance. Further insights are needed to model and integrate potential effects of CC on the evolution of LAI, $R t_{\max }$ and $R L D$ values of shallow-, medium-and deep-rooted species when assessing the efficiency of mine reclamation cover design over the long term. Preventive and/or remedial measures may be required to prevent cover performance decrease due to tree colonisation.
\end{abstract}

Keywords: cover with capillary barrier effect, climate change, tree colonisation, root penetration, mine reclamation

\section{$1 \quad$ Introduction}

Climate change (CC) is an emerging concern for the mining sector (Bussière et al. 2017; Pearce et al. 2011) and the forestry sector (Ameztegui et al. 2018; Williamson et al. 2009) in Canada. For the Québec region in Canada, Bussière et al. (2017) indicated that the highest vulnerability of the mining sector to CC is in the field of mine site reclamation. They stated that vulnerability of mining infrastructure depends among others on their lifespan and their interactions with the surrounding environment (e.g. forest ecosystems).

Engineered covers are one of the reclamation options used for the decommissioning of mine waste storage facilities to control acid mine drainage (AMD) generation (Aubertin et al. 2002, 2016). The objective of mine 
engineered cover systems is to exclude water and/or oxygen that are responsible for the AMD production when they are brought into contact with sulphide-bearing mine wastes (Aubertin et al. 2002, 2016).

Engineered cover design for mine closure used to rely on an assumption of stationarity in the relationships between physical, chemical and biological factors (DeJong et al. 2015; Fourie \& Tibbett 2007). However, under a changing climate, this assumption of stationarity is no longer valid (Bussière et al. 2017; Milly et al. 2008; Pearce et al. 2011). After mine closure, natural colonisation of plant species from the surrounding forests and adapted to current climate conditions will gradually occur on the mine sites (e.g. Guittonny et al. 2018; Laarmann et al. 2015; Smirnova et al. 2011). Plants, particularly trees with deep root systems, can affect the cover layers and eventually cause water and/or oxygen ingress to the mine wastes (Guittonny et al. 2018; Kamorina et al. 2015).

$\mathrm{CC}$ has the potential to cause shifts of the plant and animal species distribution at various scales (McKenney et al. 2007; Price et al. 2013). Temperature increase, changes in precipitation patterns, and increased frequency and magnitude of extreme events are likely to affect the structure and function of forest ecosystems in Canada (Boulanger et al. 2017; Price et al. 2013). Therefore, CC can also influence the presence and distribution of particular tree species on reclaimed mine sites that are adjacent to these forests.

In humid regions like in Québec, oxygen flux control by engineered covers is usually considered as the most efficient way to limit AMD production in the long term (Aubertin et al. 2016; Bussière et al. 2007). There are several types of oxygen barrier covers but this paper will focus on covers with capillary barrier effects (CCBEs) that have been used in the Québec region. In this reclamation technique, waste storage facilities are covered with three to five layers of materials with distinct textural and hydrogeological properties. In a CCBE, these layers are assembled in order to create capillary barrier effects (Aubertin et al. 2002, 2016). The layer made of fine-grained materials, placed on top of a coarse-grained layer that easily desaturates, tends to store moisture coming from the soil surface. Indeed, the water in the fine-grained material does not easily move downward into the underlying coarse-grained material that exhibits a low hydraulic conductivity under unsaturated conditions (Aubertin et al. 2002, 2016). The fine-grained layer is referred as the moisture retaining layer (MRL) (Aubertin et al. 2016). An additional layer of coarse-grained material is placed above the MRL to limit loss of water through evaporation (Bussière et al. 2007). Sometimes, other layers are added to protect the three core layers from erosion and bio-intrusion, and to create a favourable environment for vegetation establishment.

An adequate functioning of a CCBE relies on an MRL that should be permanently quasi-saturated (i.e. $85 \%$ or more; Aubertin et al. 2016; Bussière et al. 2007) to limit oxygen ingress to the underlying mine wastes. If more than $85 \%$ of the soil pores are filled with water, oxygen flux is low enough to limit AMD generation (Aubertin et al. 2016; Bussière et al. 2006). Plant presence on a CCBE can affect its ability to remain at a high saturation degree through water loss by transpiration, and trees are of special concern in forested regions that dominate Québec and Canada's landscapes.

The general objective of this paper is, first, to synthesise CC projections for Québec, second, to anticipate distribution changes of forest tree species under these $\mathrm{CC}$ projections and, third, to present the associated evolution of vegetation key parameters that mainly influence the plant transpiration. This collected information will be applied to the case study of the Lorraine site from Western Québec, where the potential change in tree species distribution under CC and its potential impacts on the performance of a 17-year-old CCBE will be explored.

\section{Vegetation and water distribution in oxygen barrier covers}

In Québec, plant species that are established on reclaimed mine sites by revegetation or natural colonisation can influence the water balance of engineered cover systems (Guittonny et al. 2018). Therefore, vegetation may affect the performance of a mine engineered cover by acting on one or more components of its water balance. Specifically, the influence of vegetation on the degree of saturation of some layers (e.g. MRL) of an oxygen barrier cover (e.g. CCBE) is of primary importance for its effectiveness. 


\subsection{Vegetation and water balance of covers}

Plants growing on mine tailings can have the ability to remove water through root uptake and transpiration processes (e.g. Guittonny-Larchevêque et al. 2016). Vegetation properties affect the rate and magnitude of transpiration and therefore can have a significant impact on water balance of mine covers or tailings (Albright et al. 2010; Mine Environment Neutral Drainage Program [MEND] 2014).

The general water balance can be described by Equation 1 (e.g. Hillel 1998):

$$
\Delta S=P-\left(I_{c}+R+D_{p}+E+T\right)
$$

where:

$$
\begin{array}{ll}
P & =\text { precipitation }(\mathrm{mm}) . \\
I_{c} & =\text { canopy interception }(\mathrm{mm}) . \\
R & =\text { runoff }(\mathrm{mm}) . \\
D_{p} & =\text { deep percolation }(\mathrm{mm}) . \\
E & =\text { evaporation }(\mathrm{mm}) . \\
T & =\text { transpiration }(\mathrm{mm}) . \\
\Delta S & =\text { change in soil water storage }(\mathrm{mm}) .
\end{array}
$$

Revegetation or natural colonisation of reclamation mine covers can modify their water balance, particularly storage and infiltration (Fourie \& Tibbett 2007). First, roots pump water. In the CCBE of the Lorraine site in Western Québec (Figure 1), colonised by natural vegetation for 17 years $(N=18)$, root colonisation occurred in the MRL (Guittonny et al. 2018). The authors found that water saturation (Sr) was negatively and linearly correlated with root length density (RLD, in $\mathrm{cm} / \mathrm{cm}^{3}$ ) (Pearson correlation $r=0.71, p=0.001$ ) at the surface $(0-10 \mathrm{~cm})$ of the MRL. Root colonisation and effects deeper in the MRL are under investigation. Apart from pumping water, roots also enrich cover layers in organic matter through decaying roots. Organic matter enrichment can increase the total porosity of cover material by creating macropores and thereby decrease water content $(\theta)$ and Sr (Fourie \& Tibbett 2007; Guittonny et al. 2018; Guittonny-Larchevêque et al. 2016; Larchevêque et al. 2013). Newly formed macropores can also increase the saturated hydraulic conductivity $\mathrm{k}_{\text {sat }}$ by several orders of magnitude (DeJong et al. 2015; Spain et al. 2006) by creating preferential pathways for water infiltration.

Plants species that establish on engineered covers present different morphological characteristics with varying growth rates, water use, and root strategies (Lamoureux et al. 2016). Trees with broad leaves and deeper rooting can transpire more water located at greater depths within a cover profile (Fourie \& Tibbett 2007) and even from underlying mine tailings to compensate for the water deficit in the surface layers (e.g. topsoil) (Guittonny-Larchevêque et al. 2016). Based on greenhouse and field studies, Stoltz \& Greger (2006) demonstrated that the roots of some tree species (e.g. birch, pine, spruce) were able to penetrate sealing layers such as clay and (clayey) moraine on various mine sites. Trees can access water from deeper saturated soil layers where a high fraction of roots are located (Bowling et al. 2017). Guittonny et al. (2018) found that despite a protection layer of $30 \mathrm{~cm}$ thick at the surface and the high bulk density of MRL silt $\left(1.6 \mathrm{~g} / \mathrm{cm}^{3}\right)$, roots of plants that naturally established on the Lorraine site CCBE were able to colonise the MRL 17 years after the construction of the CCBE. 


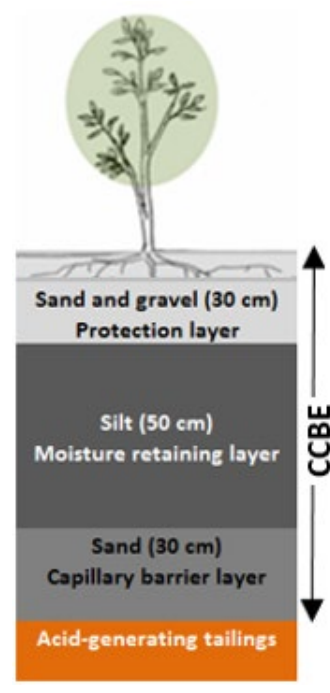

(a)

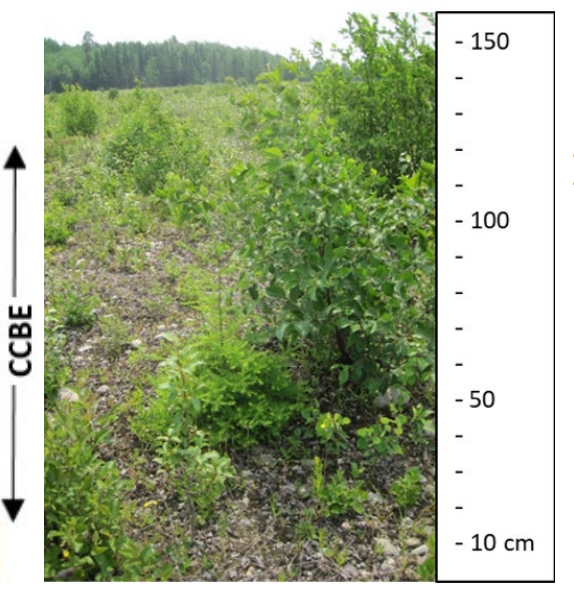

(b)

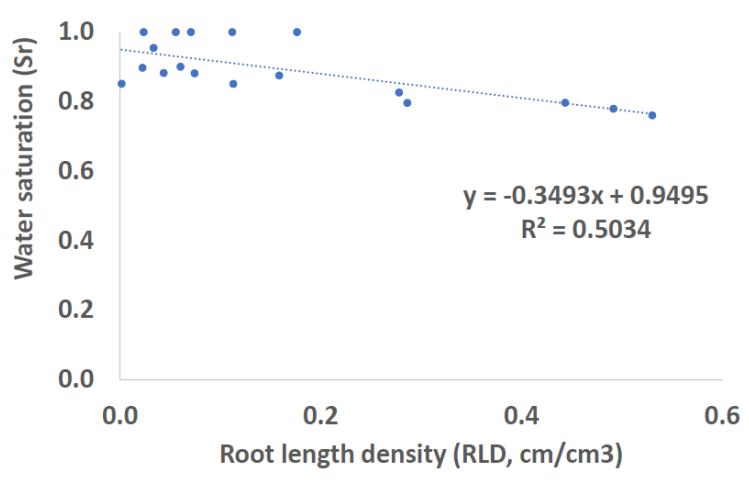

(c)

Figure 1 (a) Configuration of layers of a cover with capillary barrier effect (CCBE) established on the Lorraine mine site in 1999; (b) Picture of the vegetation found on the CCBE in July 2015; (c) Relation between root length density $\left(R L D, \mathrm{~cm} / \mathrm{cm}^{3}\right)$ at the surface of the moisture retaining layer (MRL) of the CCBE colonised by natural vegetation after 15 years and the degree of saturation ( $\mathrm{Sr}$, no units) $(\mathrm{N}=18)$ at the Lorraine mine site (Western Québec, Canada) (from Guittonny et al. 2018)

\subsection{Vegetation parameters and water distribution in covers}

Various numerical models are used in the design and performance evaluation of mine engineered cover systems (Fourie \& Tibbett 2007; MEND 2014).

The most common properties required as inputs in the most widely used numerical models are the leaf area index ( $\mathrm{LAl}$ ), the maximum depth of root penetration ( $\mathrm{Rt}_{\max }$ ) and the distribution of root density with depth (RLD). These parameters are included in numerical models to describe how vegetation influences the water balance of the engineered cover through the transpiration process.

The LAI is the ratio of leaf area available for transpiration to the area of ground surface where the plant canopy is projected. LAI varies throughout the year and as a plant matures. For modelling purposes, Albright et al. (2010) indicated that a linear function with three phases can be used to describe the temporal variation in LAI. The effect of vegetation on water loss of the mine cover layer(s) through transpiration is incorporated in the numerical water balance models through the inclusion of an evaporative term based on the LAI value(s) (e.g. Fourie \& Tibbett 2007; MEND 2014).

Root input parameters are used to describe how the root system affects transpiration through water uptake in the cover layer(s). The maximum rooting depth ( $\left.R t_{\max }\right)$ is the vertical distance at which roots extend into the cover and the RLD (i.e. root length by unit of soil volume) is used to distribute transpiration throughout the root zone (Albright et al. 2010).

\section{Effects of CC on the distribution of trees in Québec}

Mining activities in Québec require large-scale and long-term closure and reclamation plans (Ministère de l'Énergie et des Ressources Naturelles [MERN] 2017). However, these plans are often designed, approved and implemented without considering the influence of CC on hydrological and hydrogeological conditions, compromising the long-term performance of mine reclamation facilities (Bussière et al. 2017; Rooney et al. 2015). Moreover, despite the widespread agreement that CC will influence the distribution of forest tree species in Canada, its potential to affect mine closure success in the long term through tree colonisation dynamics of the reclaimed sites is generally neglected or ignored. 
By the end of the $21^{\text {st }}$ century, various studies predicted a northward shift of the distribution of some tree species from temperate to boreal regions of Canada because of CC (e.g. Berteaux et al. 2014; Boisvert-Marsh et al. 2014, 2019; McKenney et al. 2007, 2011; Price et al. 2013). These changes could significantly affect the long-term hydrogeological behaviour of mine engineered covers built to control oxygen migration.

\subsection{Trends in temperature and precipitation regimes under future climate scenarios}

CC is particularly strong at high latitudes and its effects are projected to amplify through this century at high latitudes like Northern Canada (Boisvert-Marsh et al. 2014; Price et al. 2013; Warren \& Lemmen 2014). The most recent coordinated global climate Coupled Model Intercomparison Project (CMIP5; Taylor et al. 2012) used a new set of radiative forcing scenarios called Representative Concentration Pathways (RCPs) as the basis for projecting future CC over the $21^{\text {st }}$ century (Moss et al. 2010; Warren \& Lemmen 2014). Describing trajectories of atmospheric concentration for greenhouse gases, aerosols and other air pollutants, and the resulting trajectories in net radiative forcing over time, RCPs are of particular interest to the scientific communities and the policymakers (Ouranos 2015; Warren \& Lemmen 2014). The Lorraine mine site (see Section 4: Case study) is located at the northern margin of the 'South' climate modelling reference region of Québec. Figure 2 shows the current evolution of anomalies of observed average annual temperatures (19502012) (black line with circles) for the 'South' reference region. Anomalies are calculated as departures from the reference period (here 1971-2000) average (represented by zero on the $y$-axis). The current evolution of anomalies of simulated average annual temperatures (1900-2100) for the historical period (1900-2005) and according to RCP4.5 (blue line) and RCP8.5 (red line) emission scenarios (2006-2100) for the 'South' of Québec are also presented in Figure 2. An increasing trend of air temperature shows that climate warming will be exacerbated in the coming decades (Figure 2).

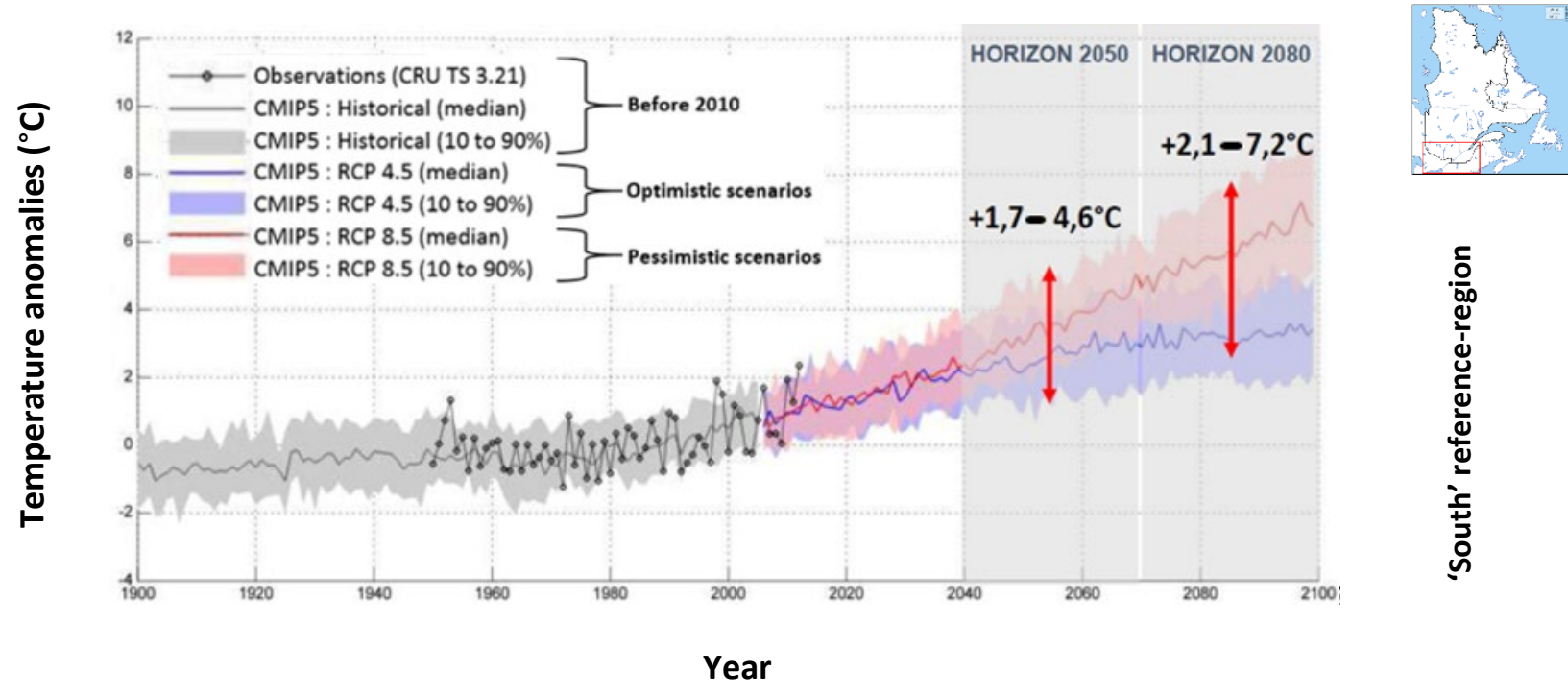

Figure 2 Evolution of temperature anomalies of observed average annual temperatures (1950-2012) and simulated ones (1900-2100) for the historical period (grey) and according to RCP4.5 (blue; $\mathrm{n}=33$ ) and RCP8.5 (red; $\mathrm{n}=29$ ) emission scenarios. Temperature anomalies are calculated based on the average 1971-2000 and are presented for the 'South' modelling sub-region of Québec (modified from Ouranos 2015)

According to current CMIP5 models, the Québec region of interest (Figure 2) could see its average annual temperature increase from $1.1^{\circ} \mathrm{C}$ to $5.4^{\circ} \mathrm{C}$ for the period $2041-2070$ (called horizon 2050) and from $1.9^{\circ} \mathrm{C}$ to $8.2^{\circ} \mathrm{C}$ for the period 2071-2100 (called horizon 2080) in comparison with 1961-1990 (called the reference period) (Berteaux et al. 2014). For all the mining regions of Québec, increases of average temperature are projected and will be more pronounced during winter particularly in the Far North. Moreover, increase in maximal amounts of precipitation is expected for all seasons as well as increase in frequencies of high (extreme) rainfall and storm events (Bussière et al. 2017; Logan et al. 2011). Projections show a decrease of 
annual soil moisture, more important during summer, for the 2018-2100 period (Ouranos 2015), as well as an extension of periods without precipitation (Bussière et al. 2017). For precipitation indicators (e.g. annual cumulative precipitation, extreme precipitation), there is an increasing trend but this is less accentuated compared to temperature. The same trend is also observed for the number of days with $\geq 10 \mathrm{~mm}$ precipitation (i.e. 'heavy precipitation days') and for accumulation during 'extreme precipitations'. The latter corresponds to the $99^{\text {th }}$ percentile value compared with the average for the 1981-2010 period. However, significant uncertainty remains about future climate conditions and the multiple, interacting impacts of CC on forest ecosystems, and forest response to those changes in Québec and other regions of Canada (Logan et al. 2011; Warren \& Lemmen 2014).

\subsection{Current distribution of dominant tree species}

The Québec province can be divided, based on edaphic and climatic conditions, into characteristic plant communities of ecological and economic importance or bioclimatic domains (Figure 3(b); Ministère des Ressources Naturelles [MRN] 2003; Périé \& De Blois 2016). Tree species occupy two vegetation zones in the Québec province: the temperate zone covered by the deciduous forest and the boreal zone covered by the coniferous forest (MRN 2003; Table 1).

The temperate zone is divided in three bioclimatic domains from south to north: sugar maple-bitternut hickory domain, sugar maple-basswood domain and sugar maple-yellow birch domain. The boreal zone is divided in five bioclimatic domains from south to north: balsam fir-yellow birch domain, balsam fir-white birch domain, spruce-moss domain, spruce-lichen domain, forest tundra domain (Berteaux et al. 2014; Gagnon 2004; MRN 2003); Table 1).

\subsection{Northward shift of tree species distribution under CC for 2100}

Future changes in temperature and precipitation patterns, and increased frequency and magnitude of extreme events, are likely to affect the structure and function of forest ecosystems in Canada (Boisvert-Marsh et al. 2014, 2019; Logan et al. 2011; Price et al. 2013). Various researchers projected northward shifts of tree species' optimal climate conditions of hundreds of kilometres for 2100 in the northern temperate and boreal forests (e.g. Berteaux et al. 2014; Boisvert-Marsh et al. 2014; McKenney et al. 2011; Périé et al. 2014; Rogers et al. 2016). In their review paper, Price et al. (2013) indicated that climate zones suitable for boreal conifers will disappear from the southern extents of their present distributions across much of Canada by 2100 . Because of the strong north-south climatic gradient in Québec, species are projected to also retract from their southern margins with CC (Périé \& De Blois 2016). However, Loarie et al. (2009) suggested that temperate broadleaf and most boreal species will be unable to spread fast enough to keep up with the rates of CC implied by most global circulation models projections. Boreal climate zones are expected to shift 5-10 times faster than the speed of natural range expansion achievable by most tree species (McKenney et al. 2007; Price et al. 2013).

Boisvert-Marsh et al. (2014) provided one of the first empirical evidences of recent latitudinal shifts for tree species in Québec based on tree saplings' occurrence patterns. They found that at least five out of the 11 species examined (Acer rubrum L., Acer saccharum Marshall, Betula papyrifera Marshall, Fagus grandifolia Ehrh. and Populus tremuloïdes Michx.) showed, over decades, significant distributional shifts consistent with northward migration. However, it is not fully understood how CC influences these patterns locally, especially in relation to other disturbances resulting from fires, insects, and diseases (Boisvert-Marsh et al. 2019; Price et al. 2013).

\section{Case study: natural tree colonisation of a CCBE on a reclaimed mine site under CC}

The Lorraine abandoned mine ( $\mathrm{Cu}$ and $\mathrm{Ni}$ ) site is located within the Témiscamingue region of South-western Québec, Canada, bordering Eastern Ontario $\left(47^{\circ} 24^{\prime} \mathrm{N}, 79^{\circ} 00^{\prime} \mathrm{W}\right.$; Figure 3) (Guittonny et al. 2018). It is an acidgenerating site of 15 ha that was reclaimed with a CCBE (Figure 1(a)). The Lorraine site is located in the 


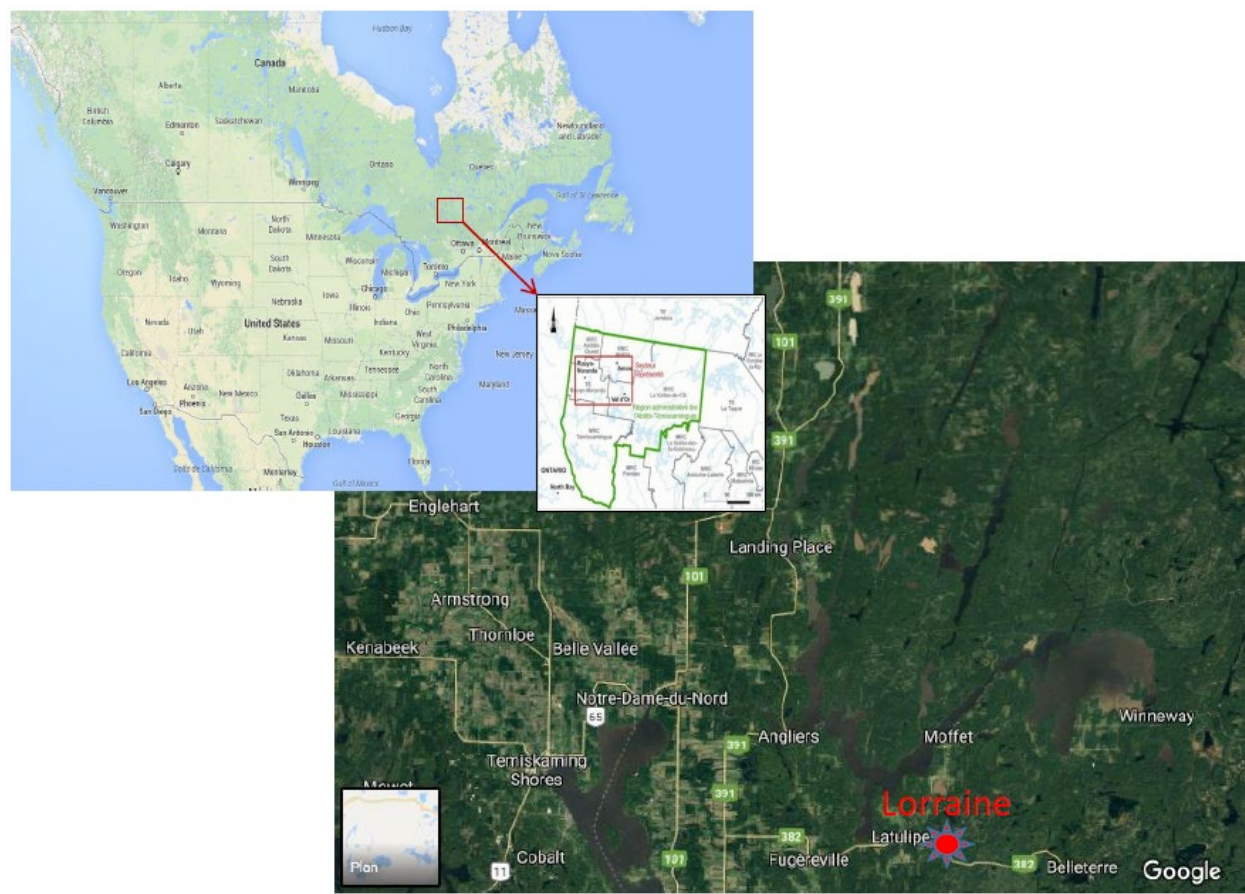

(a)

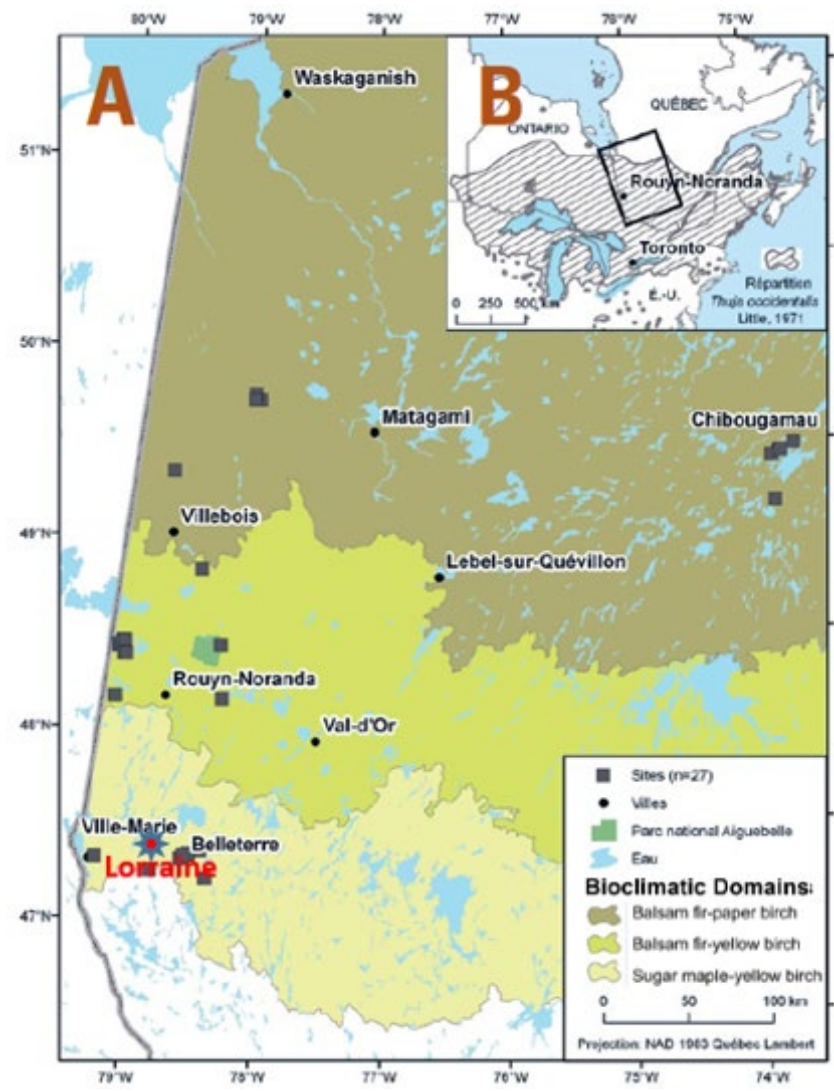

(b)

Figure 3 (a) The Lorraine abandoned mine site in the Témiscamingue region (Western Québec, Canada) bordering Eastern Ontario $\left(47^{\circ} 24^{\prime} \mathrm{N}, 7^{\circ} 00^{\prime} \mathrm{W}\right.$; $\left.79^{\circ} 00^{\prime} \mathrm{W}\right)$ (modified from Guittonny 2018); (b) Location of the Lorraine mine site within the balsam fir-yellow birch bioclimatic domain (modified from Desrochers, in Housset \& Provost n.d.) 
Western balsam fir-yellow birch bioclimatic subdomain of the boreal mixedwood forest zone (Robitaille \& Saucier 1998; Saucier et al. 2009). This is a transition zone between the northern temperate forests and the southern boreal forests, generally referred as an ecotone (Goldblum \& Rigg 2010). Williamson et al. (2009) indicated that the impacts of future regional climate on the composition, structure, and productivity of Canada's forests will be most pronounced at ecotones. Therefore, ecotones may be particularly sensitive to CC and could experience major changes in species composition (Boulanger et al. 2017). Mean temperatures (1981-2010) are $-15.5^{\circ} \mathrm{C}$ in January and $17.5^{\circ} \mathrm{C}$ in July; and total annual precipitation (1981-2010) is $693 \mathrm{~mm}$ (Rémigny station; Thibeault 2014).

\subsection{Tree (woody) vegetation composition at the Lorraine site in 2015 and 2100}

The vegetation of the Lorraine mine site has been surveyed in 2015 and the following tree species were found (Guittonny et al. 2018): Abies balsamea L. (Mill.), B. papyrifera Marshall, Picea mariana (Mill.) Britton, Pinus banksiana Lamb., Pinus resinosa Aiton, Pinus strobus L., Populus balsamifera L., P. tremuloïdes Michx. The following shrub species were also identified: Alnus rugosa (Du Roi) Spreng, Comptonia peregrina L., Kalmia $s p$. ., Larix laricina (Du Roi) K. Koch, Prunus pensylvanica L. f., Salix sp., Vaccinium sp. All these woody species dominate vegetation because they represent 51 to $75 \%$ of the total vegetation cover (Guittonny et al. 2018).

By 2100 , variations of temperature and precipitation regimes due to CC will induce a northward displacement of environmental conditions under which plant species can successfully survive and grow. For the sake of simplicity, the following hypothesis will be considered here: tree species are able to keep pace with CC, migrate northward and thrive in their new environments (referred as the best case scenario).

At the regional scale, if tree species keep pace with $\mathrm{CC}$, the balsam fir-yellow birch (BF-YB) domain (boreal-temperate forest ecosystems) in South-western Québec will move northward and should be replaced by the sugar maple-yellow birch (SM-YB) domain (temperate forest ecosystems). The SM-YB domain is mainly characterised by the following tree species dynamics (Gagnon 2004; MRN 2003):

- After fire perturbations, more shade-intolerant species will be established: deciduous trees such as P. tremuloïdes Michx., Populus grandidentata Michx., B. papyrifera Marshall, Quercus rubra L. and coniferous trees such as $P$. strobus $\mathrm{L}$.

- At late successions, more shade-tolerant species will be found: deciduous trees such as A. saccharum Marshall and A. rubrum L., and coniferous trees such as A. balsamea L. (Mill.), Picea rubens Sarg., Picea glauca (Moench) Voss and Tsuga canadensis (L.) Carriere.

Périé et al. (2014) classified 49 indigenous woody species from Québec in vulnerability groups to show the impact of CC on tree habitat suitability in 2080. The woody species were classified in six groups (A, B, C, D, E, F) from the most vulnerable species (group A: e.g. Tilia Americana L., P. banksiana Lamb.) to the least vulnerable species (group F: e.g. Salix nigra Marshall, Chamaecyparis thyoides (L.) B.S.P).

Based on current distribution (see Canada plant hardiness zones in NRCan 2017) and grouping provided by Périé et al. (2014), tree species representative of the current SM-YB domain with the highest probability to move northward and even become dominant in the adjacent boreal sub-zone (i.e. the BF-YB domain) could be identified: $P$. tremuloïdes Michx., $P$. grandidentata Michx. (after fire perturbations), A. saccharum Marshall, A. rubrum L. and Betula alleghaniensis Britton (at late successions).

Since the Lorraine mine site is located in the BF-YB domain, the surrounding forest landscape will lose most of its boreal coniferous tree species and will be mainly composed of temperate deciduous tree species by 2100. A. balsamea L. (Mill.) will migrate northward and decline in the Lorraine mine forest landscape whereas A. saccharum Marshall will become the dominant tree species along with B. alleghaniensis Britton. This is in agreement with recent studies suggesting that climate zones suitable for boreal conifers will disappear from the southern extents of their present distributions across much of Canada by 2100 (e.g. McKenney et al. 2007, 2011; Périé \& De Blois 2016). These studies also demonstrated that there will be important northward displacement of $A$. saccharum Marshall and B. alleghaniensis Britton to northern parts of Canada with CC (e.g. McKenney et al. 2007). 


\subsection{Expected changes in the values of LAI, RLD and $\mathrm{Rt}_{\max }$ at the Lorraine site due to CC}

Temperate and boreal forest tree species that colonise reclaimed mine sites have various morphological characteristics that can affect the performance of mine engineered covers (Guittonny et al. 2018; MEND 2014). Under CC, invasion by pioneer deciduous broadleaf tree species from the temperate bioclimatic regions with potentially higher $\mathrm{LAl}$ and $\mathrm{Rt}_{\max }$ values than the current tree species could negatively affect CCBE water balance on the Lorraine mine site.

Table 2 presents some LAl and $\mathrm{Rt}_{\max }$ reference values of some tree species that are of particular interest in this study. LAl values of the tree species were obtained from the Oak Ridge National Laboratory Distributed Active Archive Centre (Tennessee, USA) (lio \& Ito 2014), and $\mathrm{Rt}_{\max }$ values of the tree species from the database compiled by Fan et al. (2017). Deciduous and coniferous trees present high variability in LAl values. In current climate conditions, deciduous trees that colonise the Lorraine mine site have shallow- to mediumrooting depths. Coniferous tree species such as $A$. balsamea L. (Mill.) and P. mariana (Mill.) B.S.P. have very shallow roots whereas Pinus $s p$. have deep roots. With CC, deciduous trees with medium-rooting depths will be dominant in the forest adjacent to the mine site whereas deep-rooted coniferous trees will likely disappear from the forest landscape.

\subsection{Risks of loss of a CCBE performance due to tree colonisation in a CC context}

The main risks associated with CCBE colonisation by southern tree species at Lorraine mine site are: (i) the uptake of water from the fine-grained MRL by tree roots and (ii) the creation of macropores by roots (Guittonny et al. 2018; Kamorina et al. 2015). These risks can seriously affect the CCBE performance by decreasing its capacity to limit oxygen migration to the reactive mine wastes.

Table 2 compares levels of risks of CCBE performance loss due to transpiration (water uptake) and/or root penetration to the MRL associated with tree colonisation of the reclaimed Lorraine mine site under current and future climate.

Deciduous trees experience large changes in their LAI values that correspond to leaf-off and leaf-on stages of phenology compared to evergreen coniferous trees that exhibit lower annual LAl variations (e.g. Chen et al. 2002). However, to facilitate comparison between deciduous and coniferous tree species, Chen et al. (2002) focused on LAl distribution during midsummer (June to August) that coincides with the maximum photosynthetic capacity of the vegetation in Canada. Summer is also the most critical period when assessing the adequate functioning of the CCBE at the Lorraine mine site because it is during summer that the maximum evapo(transpi)ration rates occur.

At the Lorraine mine site, conifers will likely be replaced by broadleaved temperate deciduous trees with higher summer LAI values. As broadleaf species such as $A$. saccharum Marshall, A. rubrum L. and $B$. alleghaniensis Britton will become dominant in the landscape with $\mathrm{CC}$, they would have more influence on the CCBE water balance through important water losses by transpiration during summer. This could affect negatively the long-term performance of the CCBE through possible desaturation of the MRL.

A. balsamea L. (Mill.), B. papyrifera Marshall and P. mariana (Mill.) B.S.P. are shallow-rooting species with low probability to reach the MRL. P. balsamifera L., $P$. tremuloïdes Michx. are medium-rooting species and can more easily reach the MRL. Under CC, shallow-rooted coniferous species such as A. balsamea L. (Mill.) and deep-rooted coniferous species such as $P$. banksiana Lamb., $P$. resinosa Aiton, $P$. strobus $L$. will be absent from the surrounding forest. Additionally, Bussière et al. (2017) indicated that projections of soil moisture under CC show drier conditions particularly during summer for the period 2081-2100. This means that tree species established on the CCBE could tend to uptake water from deeper layers, particularly the MRL. Risks of serious performance loss of the CCBE could be related to important water uptake by medium-rooted species, particularly during prolonged dry periods induced by CC. 


\section{Conclusion}

Based on a comprehensive literature review of previous studies, it was shown that under CC, there will be changes in composition of the forest in Québec and particularly in the boreal mixedwood forest surrounding the Lorraine mine site (Western Québec, Canada). This will induce a change in the presence and abundance of species colonising the site after mine closure. It is expected that there will be an increase of deciduous tree species and a decline of coniferous tree species, with an expected range of LAI values from 0.4-9.9 to 0.4-8.1 and of $\mathrm{Rt}_{\max }$ values from $0.1 \mathrm{~m}-3.0 \mathrm{~m}$ to $0.1 \mathrm{~m}-3.5 \mathrm{~m}$ from 2015 to 2100 at the Lorraine mine site. This is a first step in analysing the risks of performance loss of a CCBE associated with tree colonisation of a reclaimed mine site under $C C$. Next steps will consist of modelling the influence of the evolution of vegetation parameters (e.g. LAI, RLD, $\mathrm{Rt}_{\max }$ ) on the CCBE water balance to assess the long-term performance of the CCBE under various CC scenarios. Cumulative precipitation is expected to increase with CC in Québec. This could have a positive effect on the long-term performance of oxygen barrier covers such as CCBE despite the fact that more frequent occurrence of drier periods could have an inverse effect. Therefore, the effect of vegetation and CC on tree colonisation of engineered covers like CCBEs needs to be studied together to know the resulting effect on their long-term performance. This will help in mitigating the potential negative consequences of tree colonisation on reclaimed mine sites. It will also help in improving reclamation performance, site integration to the natural landscape, and the restoration of ecosystem services affected by past mining activities.

\section{Acknowledgement}

The authors acknowledge Ressources Naturelles Canada (RNCan) for funding the study under 'Programme d'Adaptation aux Changements Climatiques de Ressources Naturelles Canada', project number AP635. 


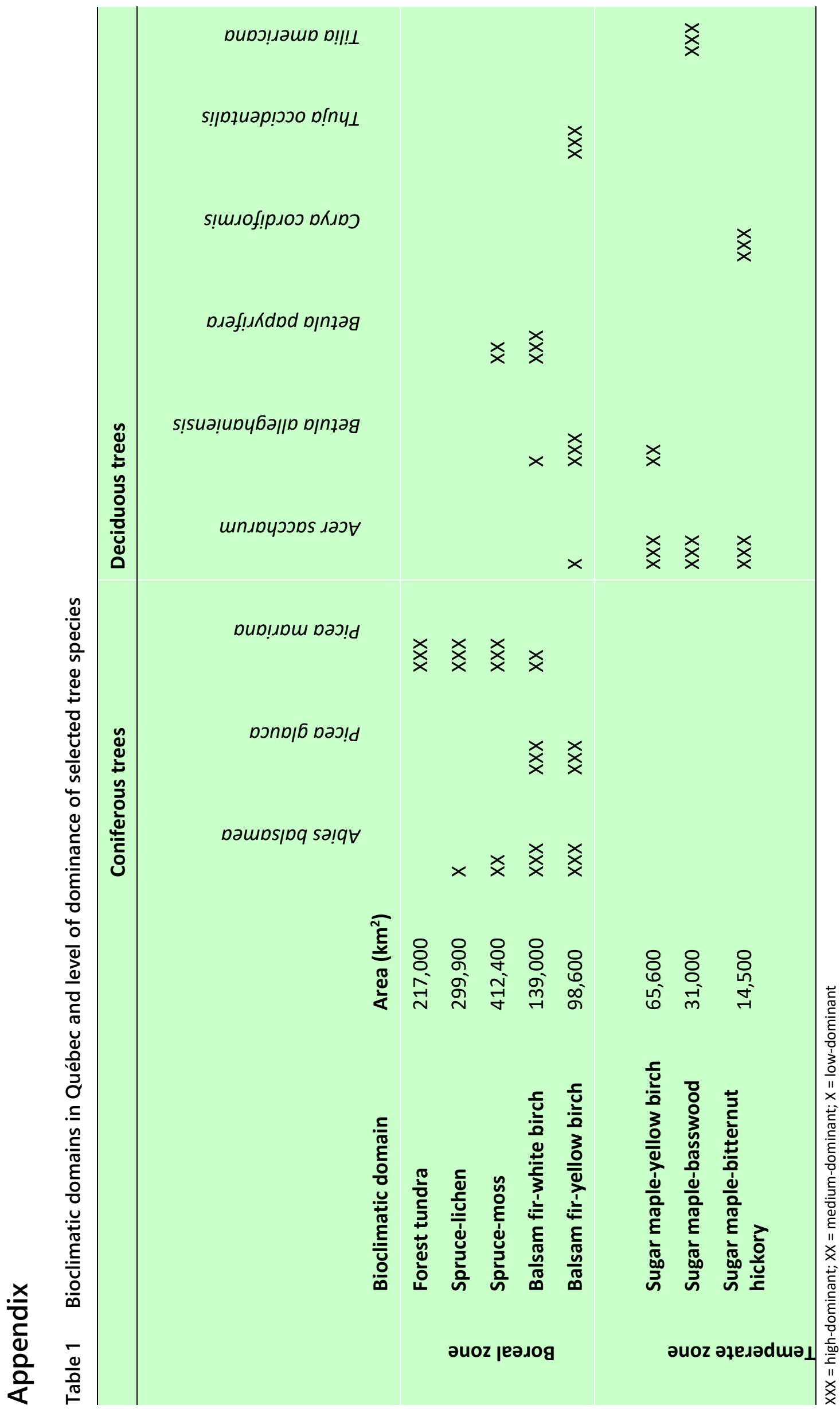




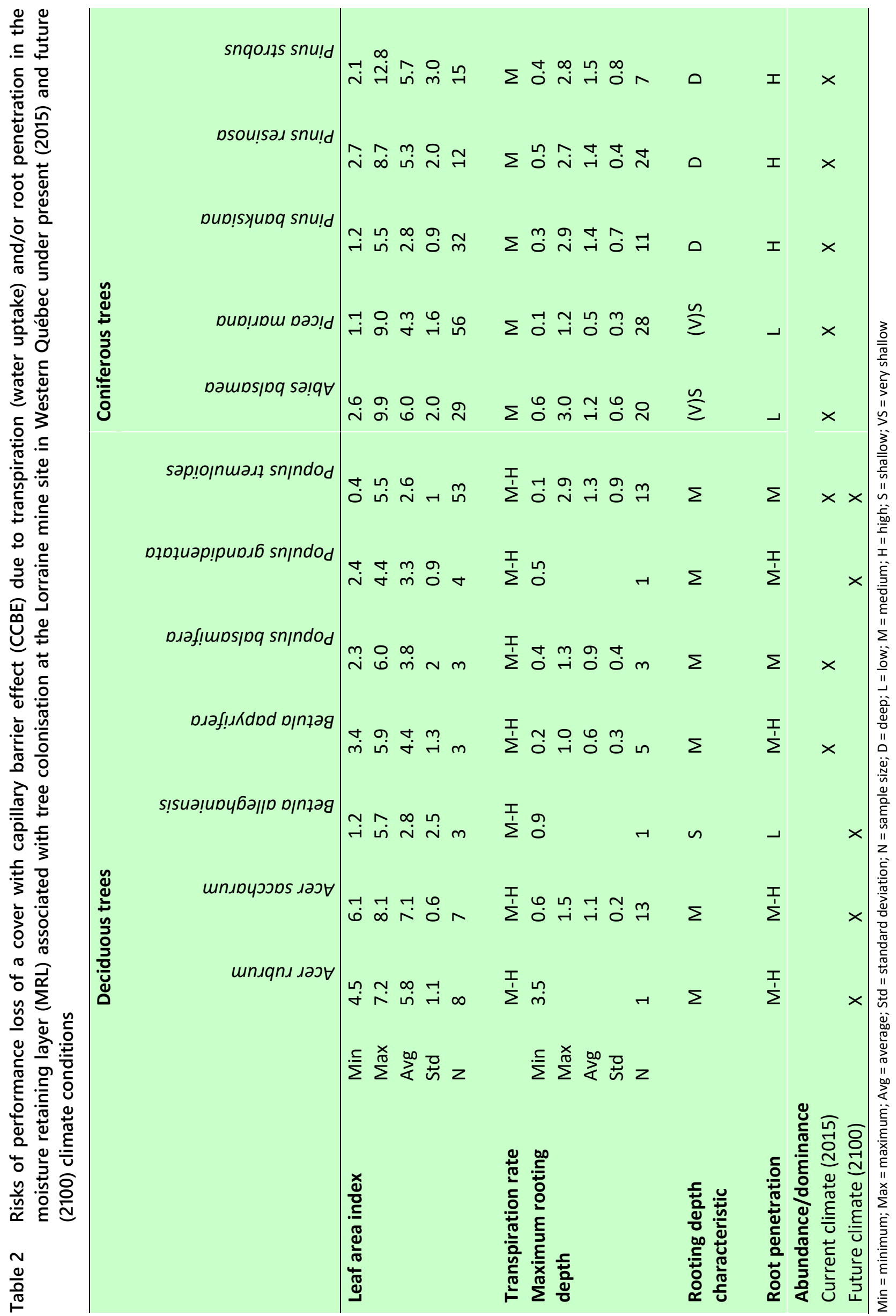




\section{References}

Albright, WH, Benson, CH \& Waugh, WJ 2010, Water Balance Covers for Waste Containment: Principles and Practice, American Society of Civil Engineers, Reston.

Ameztegui, A, Solarik, KA, Parkins, JR, Houle, D, Messier, C \& Gravel, D 2018, 'Perceptions of climate change across the Canadian forest sector: the key factors of institutional and geographical environment', PLoS ONE, vol. 13, no. 6, https://doi.org/10.1371/journal.pone.0197689

Aubertin, M, Bussière, B \& Bernier, L 2002, Environnement et Gestion des Rejets Miniers, manual on CD-ROM, Presses Internationales Polytechnique, Montréal.

Aubertin, M, Bussière, B, Pabst, T, James, M \& Mbonimpa, M 2016, 'Review of the reclamation techniques for acid-generating mine wastes upon closure of disposal sites', in D Zekkos, A Farid, A De, KR Reddy \& N Yesiller (eds), Proceedings of Geo-Chicago, American Society of Civil Engineers, Reston, pp. 343-358.

Berteaux, D, Casajus, N \& De Blois, S 2014, Changements Climatiques et Biodiversité du Québec: vers un Nouveau Patrimoine Naturel, Les Presses de I'Université du Québec, Québec.

Boisvert-Marsh, L, Périé, C \& De Blois, S 2014, 'Shifting with climate? Evidence for recent changes in tree species distribution at high latitudes', Ecosphere, vol. 5, no. 7, pp. 1-33.

Boisvert-Marsh, L, Périé, C \& De Blois, S 2019, 'Divergent responses to climate change and disturbance drive recruitment patterns underlying latitudinal shifts of tree species', Journal of Ecology, vol, 107, iss. 4, pp. 1956-1969, https://doi.org/10.1111/13652745.13149

Boulanger, Y, Taylor, A, Price, DT, Cyr, D, McGarrigle, E, Rammer, W, Sainte-Marie, G, Beaudoin, A, Guindon, L \& Mansuy, N 2017, 'Climate change impacts on forest landscapes along the Canadian southern boreal forest transition zone', Landscape Ecology, vol. 32, pp. 1415-1431.

Bowling, DR, Schulze, ES \& Hall, SJ 2017, 'Revisiting streamside trees that do not use stream water: can the two water worlds hypothesis and snowpack isotopic effects explain a missing water source?', Ecohydrology, vol. 10, iss. 1, https://doi.org/10.1002/eco.1771

Bussière, B, Aubertin, M, Mbonimpa, M, Molson, JW \& Chapuis, RP 2007, 'Field experimental cells to evaluate the hydrogeological behaviour of oxygen barriers made of silty materials', Canadian Geotechnical Journal, vol. 44, no. 3, pp. 245-265.

Bussière, B, Demers, I, Charron, P \& Bossé, B 2017, Analyse de risques et de vulnérabilité liés aux changements climatiques pour le secteur minier Québécois, Rapport final PU-2014-06-913, Ministère de l'Énergie et des Ressources Naturelles, Québec, viewed $1 \mathrm{March}$ 2019, https://mern.gouv.qc.ca/wp-content/uploads/analyse-changements-climatiques-secteur-minier.pdf

Bussière, B, Maqsoud, A, Aubertin, M, Martschuk, J, McMullen, J \& Julien, MR 2006, 'Performance of the oxygen limiting cover at the LTA site, Malartic, Québec', CIM Bulletin 99, vol. 1, no. 6, pp. 1-11.

Chen, JM, Pavlic, G, Brown, L, Cihlar, J, Leblanc, SG, White, HP, Hall, RJ, Peddle, DR, King, DJ, Trofymow, JA, Swift, E, van der Sanden, J \& Pellikka, PKE 2002, 'Derivation and validation of Canada-wide coarse-resolution leaf area index maps using high-resolution satellite imagery and ground measurements', Remote Sensing of Environment, vol. 80, pp. 165-184.

DeJong, J, Tibbett, M \& Fourie, A 2015, 'Geotechnical systems that evolve with ecological processes', Environmental Earth Sciences, vol. 73, pp. 1067-1082.

Fan, Y, Miguez-Macho, G, Jobbágy, EG, Jackson, RB \& Otero-Casal, C 2017, 'Hydrologic regulation of plant rooting depth', Proceedings of the National Academy of Sciences of the United States of America, vol. 114, no. 40, pp. 10572-10577.

Fourie, AB \& Tibbett, M 2007, 'Post-mining landforms - Engineering a biological system', in AB Fourie, M Tibbett \& JV Wiertz (eds), Proceedings of the Second International Seminar on Mine Closure, Australian Centre for Geomechanics, Perth, pp. 3-12.

Gagnon, D 2004, La Forêt Naturelle du Québec, un Survol, Rapport préparé pour la Commission d'étude sur la gestion de la forêt publique Québécoise, Université du Québec à Montréal, 74 pp.

Goldblum, D \& Rigg, LS 2010, 'The deciduous forest - boreal forest ecotone', Geography Compass, vol. 4, no. 7, pp. $701-717$.

Guittonny, M, Bussière, B, Maqsoud, A, Proteau, A, Ben Khouya, T \& Botula, Y-D 2018, 'Colonisation racinaire dans les recouvrements miniers et impact sur leur fonctionnement', Proceedings of Symposium of Mines and the Environment 2018.

Guittonny-Larchevêque, M, Bussière, B \& Pednault, C 2016, 'Tree-substrate water relations and root development in tree plantations used for mine tailings reclamation', Journal of Environmental Quality, vol. 45, pp. 1036-1045.

Hillel, D 1998, Environmental Soil Physics: Fundamentals, Applications, and Environmental Considerations, Academic Press, San Diego.

Housset, J \& Provost, M-C, n.d., Les Effets du Climat sur la Croissance du Thuya Occidental à sa Limite Nordique de Répartition au Québec, Sépaq, Québec, viewed 1 March 2019, https://www.sepaq.com/dotAsset/0cb40de6-527f-40b6-9563-d281a59aedf3.pdf

lio, A \& Ito, A 2014, A Global Database of Field-observed Leaf Area Index in Woody Plant Species, 1932-2011, data set, Oak Ridge National Laboratory Distributed Active Archive Center, Oak Ridge, viewed 1 March 2019, http://dx.doi.org/10.3334/ORNLDAAC/1231

Kamorina, G, Tremblay, F, Bussière, B, Smirnova, E \& Thiffault, N 2015, 'Bluejoint is an effective bio-barrier species on mine covers', Journal of Environmental Quality, vol. 44, pp. 1791-1799.

Laarmann, D, Korjus, H, Sims, A, Kangur, A, Kiviste, A \& Stanturf, JA 2015, 'Evaluation of afforestation development and natural colonization on a reclaimed mine site', Restoration Ecology, vol. 23, no. 3, pp. 301-310.

Lamoureux, SC, Veneklaas, EJ, Poot, P \& O'Kane, M 2016, 'The effect of cover system depth on native plant water relations in semi-arid Western Australia', in AB Fourie \& M Tibbett (eds), Proceedings of the 11th International Conference on Mine Closure, Australian Centre for Geomechanics, Perth, pp. 567-578. 
Larchevêque, M, DesRochers, A, Bussière, B, Cartier, H \& David, J-S 2013, 'Revegetation of non acid-generating, thickened tailings with boreal trees: a greenhouse study', Journal of Environmental Quality, vol. 42, pp. 351-360.

Loarie, SR, Duffy, PB, Hamilton, H, Asner, GP, Field, CB \& Ackerly, DD 2009, 'The velocity of climate change', Nature, vol. 462, pp. 1052-1055.

Logan, T, Charron, I, Chaumont, D \& Houle, D 2011, Atlas de Scénarios Climatiques pour la Forêt Québécoise: Ouranos et Ministère des Ressources naturelles et la Faune du Québec, Ouranos and Government of Québec, 55 p. +annexes.

McKenney, DW, Pedlar, JH, Lawrence, K, Campbell, K \& Hutchinson, MF 2007, 'Potential impacts of climate change on the distribution of North American trees', BioScience, vol. 57, no. 11, pp. 939-948.

McKenney, DW, Pedlar, JH, Rood, RB \& Price, D 2011, 'Revisiting projected shifts in the climate envelopes of North American trees using updated general circulation models', Global Change Biology, vol. 17, no. 8, pp. 2720-2730.

Mine Environment Neutral Drainage Program 2014, Modelling the critical interactions between cover systems and vegetation, MEND Report 2.21.6, prepared by O'Kane Consultants Inc., Report No. 702-03, viewed 1 March 2019, http://mend-nedem.org/wpcontent/uploads/2.21.6.pdf

Ministère de l'Énergie et des Ressources Naturelles 2017, Guidelines for Preparing Mine Closure Plans in Québec, Gouvernement du Québec, viewed 1 March 2019, https://mern.gouv.qc.ca/english/mines/reclamation/documents/guidelines-mine-closure.pdf

Milly, PCD, Betancourt, J, Falkenmark, M, Hirsch, RM, Kundzewicz, ZW, Lettenmaier, DP \& Stouffer, RJ 2008, 'Stationarity is dead: whither water management?', Science, vol. 319, no. 5863, pp. 573-574.

Moss, RH, Edmonds, JA, Hibbard, KA, Manning, MR, Rose, SK, van Vuuren, DP, Carter, TR, Emori, S, Kainuma, M, Kram, T, Meehl, GA, Mitchell, JFB., Nakicenovic, N, Riahi, K, Smith, SJ, Stouffer, RJ, Thomson, AM, Weyant, JP \& Wilbanks, TJ 2010, 'The next generation of scenarios for climate change research and assessment', Nature, vol. 463, pp. 747-756.

Ministère des Ressources Naturelles 2003, Vegetation zones and bioclimatic domains in Québec, Ministère des Ressources Naturelles, Direction des inventaires forestiers, Québec, viewed 1 March 2019, http://mern.gouv.qc.ca/english/publications/ forest/publications/zone-a.pdf

NRCan (Natural Resources Canada) 2017, Canada's Plant Hardiness Site: Preliminary Climatic Range Maps for 2800 Species, viewed 1 March 2019, Natural Resources Canada, Ottawa http://www.planthardiness.gc.ca/index.pl?m=13\&page=3\&biomap=1\&\&lang=en

Ouranos 2015, Vers l'adaptation: Synthèse des Connaissances sur les Changements Climatiques au Québec. Partie 1: Évolution climatique au Québec, 2014 edn, Ouranos, Montréal, 79 p.

Pearce, TD, Ford, JD, Prno, J, Duerden, F, Pittman, J, Beaumier, M, Berrang-Ford, L \& Smit, B 2011, 'Climate change and mining in Canada', Mitigation and Adaptation Strategies for Global Change, vol. 16, pp. 347-368.

Périé, C \& De Blois, S 2016, 'Dominant forest tree species are potentially vulnerable to climate change over large portions of their range even at high latitudes', PeerJ, 13 July.

Périé, C, De Blois, S, Lambert, M-C \& Casajus N 2014, Effets Anticipés des Changements Climatiques sur l'habitat des Espèces Ligneuses au Québec, Mémoire de recherche forestière n. 173, Gouvernement du Québec, Ministère des Ressources naturelles, Direction de la Recherche Forestière, Québec, viewed 1 March 2019, https://mffp.gouv.qc.ca/publications/ forets/connaissances/recherche/Perie-Catherine/Memoire173.pdf

Price, DT, Alfaro, RI, Brown, KJ, Flannigan, MD, Fleming, RA, Hogg, EH, Girardin, MP, Lakusta, T, Johnson, M, McKenney, DM, Pedlar, JH, Stratton, T, Sturrock, RN, Thompson, ID, Trofymow, JA \& Venier, LA 2013, 'Anticipating the consequences of climate change for Canada's boreal forest ecosystems', Environmental Reviews, vol. 21, pp. 322-365.

Robitaille, A \& Saucier, J-P 1998, Paysages régionaux du Québec méridional. Direction de la gestion des stocks forestiers et Direction des relations publiques, Ministère des ressources Naturelles du Québec, Les publications du Québec, Québec.

Rogers, BM, Jantz, P \& Goetz, SJ 2016, 'Vulnerability of eastern US tree species to climate change', Global Change Biology, vol. 23, pp. 3302-3320.

Rooney, RC, Robinson DT \& Petrone, R 2015, 'Megaproject reclamation and climate change', Nature Climate Change, vol. 5, pp. $963-966$.

Saucier, JP, Robitaille, A \& Grondin, P 2009, 'Cadre bioclimatique du Québec. Sous la direction de l'Ordre des Ingenieurs forestiers du Québec', Manuel de Foresterie, Éditions MultiMondes and Ordre des Ingénieurs Forestiers du Québec, pp. 186-205.

Smirnova, E, Bussière, B, Tremblay, F \& Bergeron, Y 2011, 'Vegetation succession and impacts of biointrusion on covers used to limit acid mine drainage', Journal of Environmental Quality, vol. 40, pp. 133-143.

Spain, AV, Hinz, DA, Ludwig, J, Tibbett, M \& Tongway, DJ 2006, 'Mine closure and ecosystem development: Alcan Gove bauxite mine, NT, Australia', in AB Fourie \& M Tibbett (eds), Proceedings of the First International Conference on Mine Closure, Australian Centre for Geomechanics, Perth, pp. 299-308

Stoltz, E \& Greger, M 2006, 'Root penetration through sealing layers at mine deposit sites', Waste Management \& Research, vol. 24, pp. 552-559.

Taylor, KE, Stouffer, RJ \& Meehl, GA 2012, 'An overview of CMIP5 and the experiment design', Bulletin of the American Meteorological Society, vol.93, pp. 485-498.

Thibeault, J 2014, 'Le climat dans les MRC. Deux décennies de climat', Le Bulletin, viewed 1 March 2019, http://www.mrctemiscamingue.org/wp-content/uploads/2015/09/bulletin-de-lobservatoire_2014-04.pdf

Warren, FJ \& Lemmen, DS (eds) 2014, Canada in a Changing Climate: Sector Perspectives on Impacts and Adaptation, Government of Canada, Ottawa, viewed 1 March 2019, https://www.nrcan.gc.ca/sites/www.nrcan.gc.ca/files/earthsciences/ pdf/assess/2014/pdf/Full-Report_Eng.pdf

Williamson, TB, Colombo, SJ, Duinker, PN, Gray, PA, Hennessey, RJ, Houle, D, Johnston, MH, Ogden, AE \& Spittlehouse, DL 2009, Climate change and Canada's Forests: From Impacts to Adaptation, Natural Resources Canada, Canadian Forest Service, Northern Forestry Centre, viewed 1 March 2019, http://cfs.nrcan.gc.ca/pubwarehouse/pdfs/29616.pdf 